ISSN 1991-8631

\title{
The allelopathic effects of three crop residues on the germination and radicle length of Sphenostylis sternocarpa Hochst Ex. Rich. (African Yam Bean)
}

\author{
Janet MODUPE AYENI and Joshua KAYODE* \\ Department of Plant Science, Ekiti State University, P.M.B 5663, Ado-Ekiti, Ekiti State, Nigeria. \\ "Corresponding author,E-mail: jayeni@yahoo.com; jokayode@ymail.com;
}

Tél: +2348035063504

\begin{abstract}
The allelopathic effects of aqueous extracts of Cajanus cajan stem, Maize inflorescence and Rice husk were examined on the germination and growth of Sphenostylis sternocarpa, an important indigenous pea in South Western Nigeria. The three crop extracts inhibited the germination and the lengths of radicle of this crop. The inhibition was concentration dependent as no germination was observed in the extract-treated seeds until $72 \mathrm{hrs}$ of the experiment. Analysis of the germination revealed that there were no significant $(\mathrm{P}>0.05)$ differences on the effects of extracts from the three crop residues on Sphenostylis sternocarpa at 24 hrs and 48 hrs experimental times when compared to the control experiment. At $72 \mathrm{hrs}$, there were no significant differences on the effects of Cajanus cajan stem and rice husk treated seeds when compared to the control experiment but the seeds treated with extracts from the maize inflorescences showed significant differences when compared to the control. No growth was recorded in the radicle until $96 \mathrm{hrs}$ of the experiment in all the extract - treated seeds from the three crop residues while the control germinated at 72 hours.

(c) 2013 International Formulae Group. All rights reserved.
\end{abstract}

Keywords: Allelopathy, allelochemical, biomolecules, Sphenostylis sternocarpa, inhibition, radicle.

\section{INTRODUCTION}

The term allelopathy, according to Ashrafi (2008), is a biological phenomenon by which organisms produce one or more biomolecules that influence the growth, survival and reproduction of other organisms. Allelochemicals can be present in any part of plants such as leaves, flowers, seeds, roots and fruits (Ahmad et al., 2011) from where they are released into the soil through several processes such as volatilization, leaching, root exudation, and decomposition of plant residues.
Recent initiatives have shown that allelopathy is shown in crop to crop interferences, weeds in crops and crops in weeds. Allelochemicals, according to Irshad and Cheema (2004), act by blocking hydrolysis of reserve and cell division, thus resulting in delayed or inhibited germination and the stimulation or inhibition of root and shoot growth. Abu-Romman et al. (2010) asserted that the growth cessations by allelochemicals covers all the stages from seed germination until the plant matures thus including seed germination, seedling growth, 
leaf area, dry matter, and productions. Allelopathy can also have osmotic effect by reducing water absorbing rate and thus lead to delay in seed germination and cell elongation. Chou (1990) reported that in Taiwan, rice (Oryza sativa) planted twice in a year in a monoculture system reduced the second crop yield by about $25 \%$ in area of poor water drainage. Also rice seedlings grow poorly in decomposed straw and soil mixture.

Allelopathy has also been reported from numerous crops like barley (Mostafa et al., 2008), Cucumber, oats, rice (Fudou et al., 2008), Sorghum (Khaliq et al., 2009), tobacco and wheat. In Nigeria, studies reported so far were concentrated on allelopathic effects of weeds on agricultural crops; no study had been reported on the allelopathic potentials of crop residues on crops until recently when Kayode and Ayeni (2009a; 2009b) and Ayeni et al. (2010) reported such. These crop residues are often left uncared for in the fields after harvest. The aim of this investigation therefore was to examine the allelopathic potentials of aqueous extracts from maize inflorescence, rice husk and stems of Cajanus cajan on African yam bean (Sphenostylis sterocarpa) an agricultural crop widely grown in South western Nigeria.

\section{MATERIALS AND METHODS}

Seeds of Shenosylis sterocarpa were obtained from a local market in Ikere Ekiti, a community situated at about $20 \mathrm{Km}$ from the campus of Ekiti State University, Ado- Ekiti, Nigeria. Freshly removed rice husks were obtained from a rice mill in Igbemo-Ekiti a town situated at about $10 \mathrm{~km}$ from the University while Cajanus cajan stems were obtained from a crop farm after harvesting in Ikere-Ekiti. Also, maize inflorescences were obtained from experimental site of Department of Plant Science, Ekiti State University, Ado-Ekiti, Nigeria. The Cajanus cajan stems and maize inflorescences were cut into pieces and air dried for three weeks after which they, together with the rice husk, were pounded using pestle and mortal.

Portions of $5 \mathrm{~g}, 10 \mathrm{~g}, 15 \mathrm{~g}, 20 \mathrm{~g}$, and $25 \mathrm{~g}$ were measured out from maize inflorescence, rice husk, and Cajanus cajan stem residues. Each portion was soaked in 200 $\mathrm{ml}$ of distilled water. The mixtures were shaken intermittently and left for $24 \mathrm{hrs}$ after which the extracts were filtered using Whatman No 1 filter paper and the filtrates were used afresh for the experiments. Some portions of the filtrates were kept inside the refrigerator for further usage. Two layers of Whatman No. 1 filter papers were placed in each of the Petri dish with five seeds of Sphenostylis sternocarpa. The Petri dishes were moistened daily with aqueous extracts. The treatments in each extract concentration were replicated ten times.

Control experiments with the seeds moistened with distilled water were also set up and replicated ten times. All the Petri dishes were kept in the growth chamber at room temperature. The seeds were considered germinated upon radicle emergence. The germination and radicle elongation measurements were recorded at $24 \mathrm{hrs}$ interval for six days. The results obtained from the extracts treated seeds on germination and radicle lengths were subjected to one way analysis of variance (ANOVA) using SPSS version 15 (2009) computer software. Duncan Range Multiple Test (DMRT) at 5\% probability level was used as follow up test to separate the means.

\section{RESULTS}

The allelopathic effects of aqueous extracts derived from the three crop residues on the germination of Sphenostylis sterocarpa were shown in Table 1. The aqueous extracts of the three crop residues inhibited the germination of Sphenostylis sterocarpa as no germination was recorded until $96 \mathrm{hrs}$ of the 
experiment time in the extract- treated seeds when compared to control experiment that germinated at $72 \mathrm{hrs}$ of the experiments. The only exception being $20 \mathrm{~g}$ extract concentration in the rice husk extract where germination was recorded. This tends to suggest that extracts from Cajanus cajan stem and maize inflorescence retarded Sphenostylis sternocarpa germination more than that of the rice husk.

Statistical analyses revealed that there were no significant $(\mathrm{P}>0.05)$ differences in the germination of Sphenostylis sternocarpa at the early hours of the experiment, up till 48 hrs experimental time in all the extract treated seeds. Similarly, no statistical differences were observed at $72 \mathrm{hrs}$ experimental time in the seeds treated with extracts from maize inflorescence and rice husk but statistical differences occurred in the seeds treated with extracts from the stem of $C$. cajan (Table 1). Also statistical analyses revealed that there were significant $(\mathrm{P}<0.05)$ differences in the germination of seeds treated with the extracts from the residues when compared to control experiments (in the three crop residues) from $96 \mathrm{hrs}$ to $144 \mathrm{hrs}$ experimental time. Also, the degree of inhibition increased with the increase in the concentration of the extracts, this tends to suggest that the inhibition were concentration dependent.

Table 1: Allelopathic effects of Cajanus cajan stem, maize inflorescence and rice husk aqueous extracts on the germination of Sphenostylis sternocarpa seeds.

\begin{tabular}{|c|c|c|c|c|c|c|}
\hline \multirow[t]{2}{*}{ Species/Extracts (g) } & \multicolumn{6}{|c|}{ Time (hrs) } \\
\hline & 24 & 48 & 72 & 96 & 120 & 144 \\
\hline Cajanus cajan stem 0 & $0 \mathrm{a}$ & $0 \mathrm{a}$ & $0.10 \mathrm{a}$ & $2.40 \mathrm{a}$ & $3.80 \mathrm{ab}$ & $4.70 \mathrm{ab}$ \\
\hline Cajanus cajan stem 5 & $0 \mathrm{a}$ & $0 \mathrm{a}$ & $0.00 \mathrm{~b}$ & $1.70 \mathrm{ab}$ & $3.80 \mathrm{ab}$ & $4.50 \mathrm{ab}$ \\
\hline Cajanus cajan stem 10 & $0 \mathrm{a}$ & $0 \mathrm{a}$ & $0.00 \mathrm{~b}$ & $1.10 \mathrm{bcd}$ & $3.00 \mathrm{bc}$ & $5.40 \mathrm{a}$ \\
\hline Cajanus cajan stem 15 & $0 \mathrm{a}$ & $0 \mathrm{a}$ & $0.00 \mathrm{~b}$ & $0.80 \mathrm{cde}$ & $3.00 \mathrm{bc}$ & $3.80 \mathrm{bc}$ \\
\hline Cajanus cajan stem 20 & $0 \mathrm{a}$ & $0 \mathrm{a}$ & $0.00 \mathrm{~b}$ & $0.60 \mathrm{cde}$ & $3.00 \mathrm{bc}$ & $4.00 \mathrm{bc}$ \\
\hline Cajanus cajan stem 25 & $0 \mathrm{a}$ & $0 \mathrm{a}$ & $0.00 \mathrm{~b}$ & $0.50 \mathrm{cde}$ & $3.10 \mathrm{bc}$ & $3.70 \mathrm{bc}$ \\
\hline Maize inflorescence 0 & $0 \mathrm{a}$ & $0 \mathrm{a}$ & $0.60 \mathrm{a}$ & $2.40 \mathrm{a}$ & $4.40 \mathrm{a}$ & $4.80 \mathrm{ab}$ \\
\hline Maize inflorescence 5 & $0 \mathrm{a}$ & $0 \mathrm{a}$ & $0.00 \mathrm{~b}$ & $0.90 \mathrm{bcde}$ & $3.30 \mathrm{abc}$ & $4.60 \mathrm{ab}$ \\
\hline Maize inflorescence 10 & $0 \mathrm{a}$ & $0 \mathrm{a}$ & $0.00 \mathrm{~b}$ & $0.45 \mathrm{cde}$ & $2.25 \mathrm{de}$ & $3.85 \mathrm{bc}$ \\
\hline Maize inflorescence 15 & $0 \mathrm{a}$ & $0 \mathrm{a}$ & $0.00 \mathrm{~b}$ & $0.20 \mathrm{de}$ & $1.35 \mathrm{~d}$ & $3.10 \mathrm{c}$ \\
\hline Maize inflorescence 20 & $0 \mathrm{a}$ & $0 \mathrm{a}$ & $0.00 \mathrm{~b}$ & $0.10 \mathrm{~d}$ & $0.20 \mathrm{~d}$ & $0.35 \mathrm{~d}$ \\
\hline Maize inflorescence 25 & $0 \mathrm{a}$ & $0 \mathrm{a}$ & $0.00 \mathrm{~b}$ & $0.10 \mathrm{~d}$ & $0.20 \mathrm{~d}$ & $0.30 \mathrm{~d}$ \\
\hline Rice husk 0 & $0 \mathrm{a}$ & $0 \mathrm{a}$ & $0.20 \mathrm{a}$ & $1.30 \mathrm{bc}$ & $3.90 \mathrm{ab}$ & $4.60 \mathrm{ab}$ \\
\hline Rice husk 5 & $0 \mathrm{a}$ & $0 \mathrm{a}$ & $0.00 \mathrm{~b}$ & $0.60 \mathrm{c}$ & $3.40 \mathrm{abc}$ & $4.20 \mathrm{abc}$ \\
\hline Rice husk 10 & $0 \mathrm{a}$ & $0 \mathrm{a}$ & $0.00 \mathrm{~b}$ & $0.50 \mathrm{cde}$ & $3.10 \mathrm{c}$ & $4.10 \mathrm{bc}$ \\
\hline Rice husk 15 & $0 \mathrm{a}$ & $0 \mathrm{a}$ & $0.00 \mathrm{~b}$ & $0.50 \mathrm{cde}$ & $3.00 \mathrm{bc}$ & $4.20 \mathrm{abc}$ \\
\hline Rice husk 20 & $0 \mathrm{a}$ & $0 \mathrm{a}$ & $0.10 b$ & $0.30 \mathrm{de}$ & $2.80 \mathrm{bc}$ & $4.00 \mathrm{bc}$ \\
\hline Rice husk 25 & $0 \mathrm{a}$ & $0 \mathrm{a}$ & $0.00 \mathrm{~b}$ & $0.03 \mathrm{de}$ & $2.70 \mathrm{bc}$ & $3.90 \mathrm{bc}$ \\
\hline
\end{tabular}

Means followed by the same letter within column are not significantly different $(\mathrm{P}>0.05)$. 
The effects of the aqueous extracts of Cajanus cajan stem, rice husk and maize inflorescence on the radicle lengths of Sphenostylis sternocarpa is shown in Table 2. The results showed that extracts from the three crop residues retarded the radicle lengths of Sphenostylis sternocarpa. No radicle growth was recorded until 96 hrs of the experiment in the extracts-treated seeds. Statistical analysis revealed that there were no significant $(\mathrm{P}>0.05)$ differences in the radicle lengths in the extract treated seeds when compared to that of the control up till $48 \mathrm{hrs}$ experimental time in all the extracts. At $72 \mathrm{hrs}$ experimental time, significant differences abound in the extract-treated seeds and the control, in the $25 \mathrm{~g}$ C. cajan extract treated- seeds and all the concentrations examined in the maize inflorescence extracts but no such differences were observed in the rice husk extracts even up till 96 hrs experimental time (Table 2). Similarly, significant differences abound at $96 \mathrm{hrs}$ period and above in the $C$. cajan and maize inflorescence extracts.

Results in Table 2 also revealed that the degree of retardations experienced on the radicle increases with the increase in the concentrations of the extracts. This further confirmed that the inhibition experienced is concentration dependent. It could be inferred from this study that allelochemicals contained in these residues impaired growth in the Sphenostylis sternocarpa.

Table 2: Allelopathic effects of Cajanus cajan stem maize inflorescence and rice husk aqueous extracts on the radicle length $(\mathrm{cm})$ of Sphenostylis sternocarpa seeds.

\begin{tabular}{lcccccc}
\hline Species/Extracts (g) & \multicolumn{7}{c}{ Time (hrs) } \\
\cline { 2 - 7 } & $\mathbf{2 4}$ & $\mathbf{4 8}$ & $\mathbf{7 2}$ & $\mathbf{9 6}$ & $\mathbf{1 2 0}$ & $\mathbf{1 4 4}$ \\
\hline Cajanus cajan stem 0 & 0a & 0a & $0.00 \mathrm{~b}$ & $0.12 \mathrm{a}$ & $0.85 \mathrm{a}$ & $1.16 \mathrm{a}$ \\
Cajanus cajan stem 5 & 0a & 0a & $0.00 \mathrm{~b}$ & $0.11 \mathrm{~b}$ & $0.48 \mathrm{dc}$ & $1.12 \mathrm{abc}$ \\
Cajanus cajan stem 10 & 0a & 0a & $0.00 \mathrm{~b}$ & $0.06 \mathrm{~b}$ & $0.45 \mathrm{dc}$ & $0.89 \mathrm{abcdef}$ \\
Cajanus cajan stem 15 & 0a & 0a & $0.00 \mathrm{~b}$ & $0.06 \mathrm{~b}$ & $0.42 \mathrm{dc}$ & $0.86 \mathrm{abcdef}$ \\
Cajanus cajan stem 20 & 0a & 0a & $0.00 \mathrm{~b}$ & $0.00 \mathrm{~b}$ & $0.41 \mathrm{dc}$ & $0.75 \mathrm{cdef}$ \\
Cajanus cajan stem 25 & 0a & $0 \mathrm{a}$ & $0.00 \mathrm{~b}$ & $0.00 \mathrm{~b}$ & $0.39 \mathrm{dc}$ & $0.70 \mathrm{def}$ \\
\hline Maize inflorescence 0 & 0a & $0 \mathrm{a}$ & $0.00 \mathrm{~b}$ & $0.31 \mathrm{a}$ & $0.82 \mathrm{ab}$ & $1.15 \mathrm{ab}$ \\
Maize inflorescence 5 & 0a & $0 \mathrm{a}$ & $0.00 \mathrm{~b}$ & $0.09 \mathrm{~b}$ & $0.52 \mathrm{c}$ & $0.86 \mathrm{abcdef}$ \\
Maize inflorescence 10 & 0a & $0 \mathrm{a}$ & $0.00 \mathrm{~b}$ & $0.02 \mathrm{~b}$ & $0.41 \mathrm{dc}$ & $0.72 \mathrm{def}$ \\
Maize inflorescence 15 & 0a & $0 \mathrm{a}$ & $0.00 \mathrm{~b}$ & $0.01 \mathrm{~b}$ & $0.22 \mathrm{~d}$ & $0.64 \mathrm{f}$ \\
Maize inflorescence 20 & 0a & $0 \mathrm{a}$ & $0.00 \mathrm{~b}$ & $0.00 \mathrm{~b}$ & $0.00 \mathrm{~b}$ & $0.00 \mathrm{~b}$ \\
Maize inflorescence 25 & 0a & $0 \mathrm{a}$ & $0.00 \mathrm{~b}$ & $0.00 \mathrm{~b}$ & $0.00 \mathrm{~b}$ & $0.00 \mathrm{~b}$ \\
\hline Rice husk 0 & 0a & $0 \mathrm{a}$ & $0.00 \mathrm{~b}$ & $0.12 \mathrm{a}$ & $0.66 \mathrm{abc}$ & $1.07 \mathrm{abcd}$ \\
Rice husk 5 & 0a & $0 \mathrm{a}$ & $0.00 \mathrm{~b}$ & $0.00 \mathrm{~b}$ & $0.61 \mathrm{abc}$ & $1.04 \mathrm{abcde}$ \\
Rice husk 10 & 0a & $0 \mathrm{a}$ & $0.00 \mathrm{~b}$ & $0.00 \mathrm{~b}$ & $0.57 \mathrm{bc}$ & $0.79 \mathrm{bcdef}$ \\
Rice husk 15 & 0a & 0a & $0.00 \mathrm{~b}$ & $0.00 \mathrm{~b}$ & $0.53 \mathrm{c}$ & $0.77 \mathrm{abcd}$ \\
Rice husk 20 & 0a & 0a & $0.00 \mathrm{~b}$ & $0.00 \mathrm{~b}$ & $0.46 \mathrm{dc}$ & $0.68 \mathrm{ef}$ \\
Rice husk 25 & 0a & 0a & $0.00 \mathrm{~b}$ & $0.00 \mathrm{~b}$ & $0.23 \mathrm{~d}$ & $0.60 \mathrm{f}$ \\
\hline
\end{tabular}

Means followed by the same letter within column are not significantly different $(\mathrm{P}>0.05)$. 


\section{DISCUSSION}

This study tends to corroborate the previous assertions of previous researchers such as Khaliq et al. (2009), Hu et al. (2009), Fuduo et al. (2008) that allelochemicals often result in considerable reduction in growth of some crops. Kayode and Ayeni (2009a) revealed that allelochemicals in rice residues had been identified to be phenolic compounds such as p- hyroxybenzoic, vallinic, ferrulic, pcoumaric acid and an o-hydroxy phenyl acetic acid. Santana et al. (2009) asserted that these phenolic derivatives are extremely phytotoxic. Also, Sanchez- Moneira (2004) attributed the allelopathy in maize inflorescence to hydroxamic while Nulifer et al. (2006) revealed that the phenolic acids and carbohydrates in pigeon pea (Cajanus cajan) plant include protocatechuic, phydroxybenzoic acid, vallinic, caffeic, pcoumaric and ferrulic acids. In conclusion, these allelochemicals were suspected to be responsible for the retardation in germination and radicle growth of Sphenostylis sternocarpa examined in this study.

\section{REFERENCES}

Abu-Romman S, Shatnawi M, Shibli RS. 2010. Allelopathic effects of Spurge (Euphorbia hierosigmitana) on wheat (Triticum durum). American Eurasian J. Agric. Environ. Sci., 7(3): 298-302.

Ahmad S, Arfan M, Khan AL, Ullah R, HussainJ, Muhammad Z, Khan R, Khan N, Watanabe N. 2011. Allelopathy of Teucrium royleanum Wall. Ex. Benth. Pakistan J. Med. Plants. Res., 5(5): 765772.

Ashrafi ZY, Sadegh S,Mashhadi HR, Hassan MA. 2008. Allelopathic effects of Sunflower (Helianthus annus) on germination and growth of wild barley (Hordeum spontaneum). J. Agric. Tech., 4(1): 219-229.
Ayeni JM, Kayode J, Tedela OP. 2010. Allelopathic Potentials of Some Crop Residues on the Germination and Growth of Bidens pilosa L. Journal of Agricultural Science and Technology, 4: 21-24.

Chuo CH. 1990. The role of allelopathy in agro ecosystem studies from tropical Taiwan. Ecological Studies, 78: 105-121.

Fudou Z, Tianlin L, Qinli S, Yiqing G, Peng X, Fengyi H, Dayun T. 2008. Weedsuppression ability of Oryza longistaminata and Oryza sativa. Allelopathy J., 22: 345.

Gill LS, Anoliefo GO, Iduoze UV. 1993. Allelopathic effect of aqueous extracts from Siam weed on growth of cowpea. Chromoleana Newsletters, 8: 1-11.

Hu F, Wang D, Chen XH, Ding GL. 2008. Allelopathic potential of rice accessions against barnyard grass in paddy field. Allelopathy J., 22: 379-384.

Irshad A, Cheema ZA. 2004. Influence of some plant water extract on the germination and seedling growth of Barnyard grass $[E . \quad$ crus-galli (L.) Beauv.]. Pak. Sci. Ind. Res., 47(3): 222 226.

Kayode J, Ayeni JM. 2009a. Allelopathic Effects of some Crop Residues on the germination and Growth of Cowpea (Vigna unguiculata L. Walp). Ethnobotanical Leaflets, 13: 343 -350.

Kayode J, Ayeni JM. 2009b. Allelopathic effect of some crop residues on the germination and Growth of Zea mays (L). The Pacific Journal of Science and Technology, 10(1): $\quad 345-349$.

Khaliq A, Matloob A, Mushtag MN, Aslam F. 2009. Inhibitory effects of Sorghum and Sunflower water extracts on germination and growth of Cichorium intybus L. roceedings, $1^{\text {st }}$ Asian Allelopathy Society 
(AAS). December 18-22, 2009, Gaunzhou, China, 110-125.

Mostafa O, Hamid RM, Mohammad AB, Hassan MA, Samira B. 2008. Assesment of allelopathic potentials of 17 Iranian barley cultivars in different development stages and their variations over 60years of selection. Weed Biology and Management, 8: 225-232.

Nulifer N, Mosihuzzaman M, OlofTheander. 2006. Analysis of phenolic acids and carbohydrates in pigeon pea (Cajanus cajan). Plant Journal of the Science of Food \& Agric., 80(1): 45 - 53.
Sanchez-Moreiras AM, Tloba de la P, Martinez A, Gonzalez L, Pellisier F, Regiosa M. 2004. Mode of action of hydroxamic acid (BOA) and other related compounds. In Allelopathy: Chemistry and Mode of Action of Allelochemical, Marcias FA (ed), CRC Press: New York; 239-252.

Santana CM, Ferrera ZA, Padron MET, Rodniquez JSS. 2009. Methodologies for the extraction of phenolic compound from environmental samples. New Approaches Molecule, 14: 298-320. 